\title{
A new species of Australopericoma Vaillant (Diptera, Psychodidae) from the Brazilian semi-arid region
}

\author{
Freddy Bravo \\ Biota Neotropica $v 7(n 2)$ \\ http://www.biotaneotropica.org.br/v7n2/pt/abstract?short-communication+bn04507022007 \\ Recebido em 20/04/07 \\ Versão reformulada recebida em 30/06/07 \\ Publicado em 28/07/07 \\ Departamento de Ciências Biológicas, Universidade Estadual de Feira de Santana - UEFS, \\ Av. Universitária s/n, CEP 44031-460, Feira de Santana, BA, Brazil, \\ e-mail:freddy11bravo@yahoo.com.br,fbravo@uefs.br
}

\begin{abstract}
Bravo, F. A new species of Australopericoma Vaillant (Diptera, Psychodidae) from the Brazilian semi-arid region. Biota Neotrop. May/Aug 2007 vol. 7, no. 2. http://www.biotaneotropica.org.br/v7n2/pt/abstract?shortcommunication+bn04507022007. ISSN 1676-0603.

A new species of Australopericoma Vaillant from Brazil is described and illustrated. It is the first record of Australopericoma from the semi-arid region of northeastern Brazil.

Keywords: Diptera, Psychodidae, Australopericoma, new species, Caatinga, Brazil.

Resumo

Bravo, F. Espécie nova de Australopericoma Vaillant (Diptera, Psychodidae) do Semi-árido Brasileiro. Biota Neotrop. May/Aug 2007 vol. 7, no. 2. http://www.biotaneotropica.org.br/v7n2/pt/abstract?shortcommunication+bn04507022007. ISSN 1676-0603.

Uma nova espécie de Australopericoma Vaillant do Brasil é descrita. Este trabalho apresenta o primeiro registro de Australopericoma do semi-árido do nordeste brasileiro.

Palavras-chave: Diptera, Psychodidae, Australopericoma, espécie nova, Caatinga, Brasil.
\end{abstract}




\section{Introduction}

The genus Australopericoma Vaillant comprises 14 species from the Neotropics (Quate \& Brown 2004): Australopericoma caudata (Satchell) occurs widely in the USA (Florida, Texas, Arizona) and in the Caribbean (Jamaica) (Quate 1955, Quate \& Brown 2004); 2 species from Costa Rica (A. saggita Quate \& Brown and A. cesticella Quate \& Brown); 1 species from Trinidad (A.trinidadensis Quate \& Brown); 3 species form Venezuela (A. abnormalis Quate \& Brown, A. curvata Quate \& Brown and A. falcata Quate \& Brown); 1 species from Colombia (A. roessleri (Wagner \& Joost)); 2 species from Peru (A. exilis Quate \& Brown and A. bhati Quate \& Brown); 1 species from Argentina (A. pallidula (Tonnoir)). The other 3 species of Australopericoma are known from Brazil, all of them from the state of Rondônia in the Brazilian Amazon (Quate \& Brown 2004): A. pontilis Quate \& Brown, A. multifida Quate \& Brown, and A. bulbula Quate \& Brown. A new species of Australopericoma from the Brazilian semi-arid region is described here, based on specimens from two localities of Bahia State.

\section{Materials and Methods}

All specimens examined were captured in a light trap, and were subsequently treated with $10 \% \mathrm{KOH}$, dehidrated and mounted in Canada balsam. Morphological terminology follows that of McAlpine (1981). The specific morphological terminology for Psychodidae follows that of Duckhouse (1990) and Bravo (2006). The term "foramen" used by Quate \& Brown (2004) is preferred over "pseudospiracular opening" as used by Duckhouse (1990). The term "sternite 10" of McAlpine (1981) is accepted for the large sclerite known as the "ventral epandrial plate" according to Duckhouse (1990), or as the "ventral epandrial sclerite" of Quate \& Brown (2004). The specimens were deposited in the Coleção Entomológica do Museu de Zoologia da Universidade Estadual de Feira de Santana, Feira de Santana, Bahia, Brazil (MZUEFS), Museu de Zoologia da Universidade de São Paulo (MZUSP) and Coleção de Invertebrados do Instituto Nacional de Pesquisas da Amazônia (INPA).

\section{Results}

\section{Australopericoma dissimilis Bravo, sp. nov.}

Type material. Brazil, Bahia, Pilão Arcado municipality, Brejo do Zacarias (10 $07^{\circ}$ S $42^{\circ} 53^{\prime}$ W, 390 m), 03.XII.2005, Vieira, R. \& Alvim, E. col., holotype male (MZUEFS); 41 paratype males and 89 paratype females with same locality, date, and collectors as holotype (MZUEFS, MZUSP, INPA); Vitória da Conquista munici-

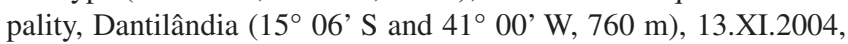
Chagas, C. \& Vieira, R. col., 2 paratype males and 1 paratype female (MZUEFS).

Etymology. The species specific name dissimilis is Latin, and refers to the asymmetric format of the hypandrium.

Diagnosis. Male with asymmetrical hypandrium, H-shape; the dorsal surface of hipandrium with micropilosity and ventral surface with long bristles in the apex of the arms. Apical lobes of subgenital plate of female with sides divergent and separated by a shallow apical concavity.

\section{Description}

\section{Male}

Eye bridge with 3 facet rows, separated by 0.5 facet diameters (Figure 1). Interocular suture present, without spur (Figure 1). An- tenna shorter than wing; scape cylindrical, $1.4 \mathrm{X}$ length of pedicel (Figure 2); pedicel spherical (Figure 2); 14 flagellomeres present (Figures 3,4); basal flagellomeres fusiform (Figure 4); 3 last flagellomeres reduced, $14^{\text {th }}$ with long apiculus (Figure 3 ); $1^{\text {st }}$ flagellomere without ascoids (Figure 4), $2^{\text {nd }}$ to $11^{\text {th }}$ with pair of C-shaped ascoids, shorter than the segment bearing them (Figures 3, 4). Labellum with bristles on apex (Figure 5). Palpus formula = 1.0:1.2:1.2:1.7 (Figures 1,6); last palpomere striated (Figure 6). Wing (Figure 7) with short Sc; medial fork apical to radial fork; $\mathrm{R}_{5}$ ending at wing tip. Male terminalia: epandrium pilose, rectangular, distal margin concave (Figures 9, 11); presence of two foramina near the proximal margin (Figure 11). Cercus long, 1.2X length of epandrium, with 1 apical tenaculum on the apex (Figure 9); internal surface of the cercus with 5 long bristles near the base (Figure 8). Tergite 10 semicircular with small bristles in the apex (Figure 11). Hypandrium: asymmetrical, H-shape (Figures $13,14,15)$; ventral surface with semicircular membranous area and with long bristles on the apices of the arms (Figure 14); dorsal surface with distal micropilosity (Figure 15); in the short distal arm is observed a little lobe that is an extension of the ventral surface of the same arm. Gonocoxite pilose, 1.7X length of gonostyle (Figure 13). Gonostylus pilose, with two long apical bristles and one long basal bristle (Figure 10). Gonocoxal apodeme with anterior surface triangular, bifurcated and with a dorsal membranous area (Figure 16); posterior surface of gonocoxal apodeme with two dorsal hemispheric

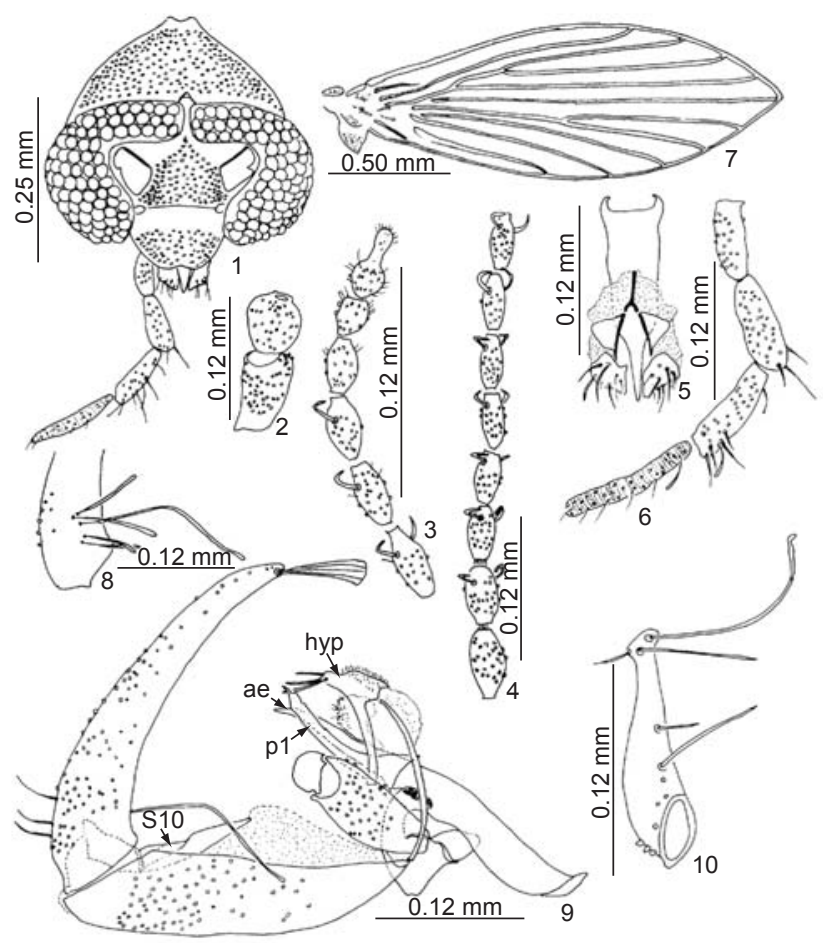

Figures 1-10. Australopericoma dissimilis Bravo, sp. nov. Male. 1. Head. 2. Antenna: scape and pedicel. 3. Antenna, flagelomeres 9-14. 4. Antenna, flagelomeres 1-8. 5. Labella. 6. Palpus. 7. Wing. 8. Cercus, base with five bristles. 9. Male terminalia, lateral. 10. Gonostyle. ae = aedeagus; hyp $=$ hypandrium; $\mathrm{p} 1=$ paramere with 3 armas; $\mathrm{S} 10=$ sternite 10 .

Figuras 1-10. Australopericoma dissimilis Bravo, sp. nov. Macho. 1. Cabeça. 2. Antena: escapo e pedicelo. 3. Antena, flagelômeros 9-14. 4. Antena, flagelômeros 1-8. 5. Labela. 6. Palpo. 7. Asa. 8. Cerco, base com 5 cerdas. 9. Terminália masculina, lateral. 10. Gonóstilo. Ae = edeago; hyp = hipândrio; p1 = parâmero com 3 braços; S10 = esternito 10 . 
lobes, the left one with small sclerotized area (Figure 16). Sternite 10 with two sclerites, a basal one, less sclerotized, triangular and with a pair of lateral sclerites, and the apical one, sub-rectangular with an apical protuberance (Figures 11, 12). Aedeagus asymmetric, curved apically (Figure 13). Aedeagal apodeme subrectangular, longer than the aedeagus, with anterior keel (Figure 13). Paramere pairs asymmetrical: p1 complex, with 3 arms (Figure 13): external arm small (Figure 13: ex), medial arm digitiform with small projections at the apex (Figure 13: md), internal arm triangular and curved (Figure 13: in); p2 simple, triangular, with small projection at the apex.

\section{Female}

Similar to male except as follows: Apical lobes of subgenital plate of female (S8) with sides divergent and separated by a shallow apical concavity. Chitinous arch ends well before apical margin.

\section{Habitat}

The new taxa, A. dissimilis sp. nov., is the first species described for this genus from the Brazilian semi-arid caatinga biome. This biome is characterized by a long dry season (6-11 months) and low precipitation levels (300-1000 mm/year), with rainfall usually occurring between November and March (Behling et al. 2000; Queiroz, 2006). The caatinga vegetation may be described as a dry forest of

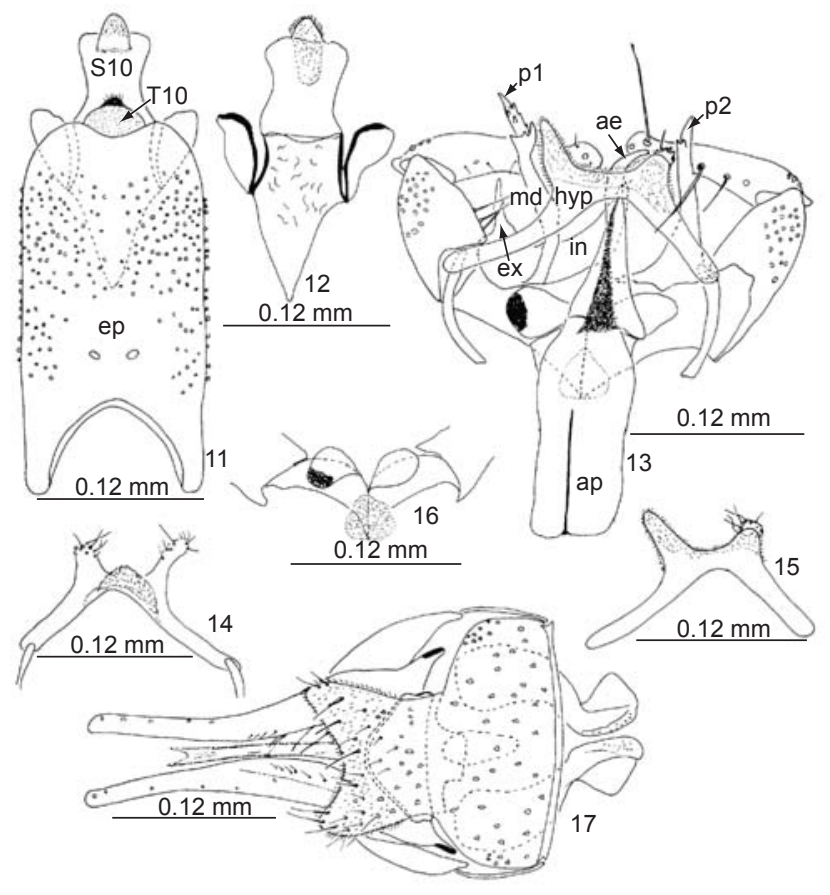

Figures 11-17. Australopericoma dissimilis Bravo, sp. nov. Male, 1-16. Female, 17. 11. Male terminalia, ventral. 12. Sternite 10. 13. Male terminalia, dorsal. 14. Hypandrium, ventral. 15. Hypandrium, dorsal.16. Gonocoxal apodeme. 17. Female terminalia. ae = aedeagus; ep = epandrium; ap+ Aedeagal apodeme; hyp = hypandrium; $\mathrm{p} 1$ and $\mathrm{p} 2=$ parameres $(\mathrm{ex}=$ external arm, $\mathrm{md}=$ medial $\mathrm{arm}$, in $=$ internal $\mathrm{arm}) ; \mathrm{S} 10=$ sternite $10 ; \mathrm{T} 10=$ tergite 10 .

Figuras 11-17. Australopericoma dissimilis Bravo, sp. nov. Macho, 1-16. Fêmea, 17. 11. Terminália masculina, ventral. 12. Esternito 10. 13. Terminália masculina, dorsal. 14. Hipândrio, ventral. 15. Hipândrio, dorsal. 16 Apódema gonocoxal. 17 Terminália feminina. ae = edeago; ep = epándrio; ap = apódema edeagal; hyp = hipândrio; p1 e p2 = parâmeros $(\mathrm{ex}=$ braço externo; $\mathrm{md}$ = braço médio; in = braço interno); $\mathrm{S} 10=$ esternito $10 ; \mathrm{T} 10=$ tergito 10 . mostly small trees and shrubs, usually with twisted trunks and thorns, with small leaves that are deciduous in the dry season. Cactaceae are common in the caatinga, while an ephemeral herbaceous layer is observed only during the short rainy season (Queiroz, 2006).

The localities where the new species were collected (Pilão Arcado and Dantilândia) are separated by $600 \mathrm{~km}$. Pilão Arcado is located on the sand dunes of the middle São Francisco River, in northern Bahia State, in a region of hyperxerophytic caatinga (Barreto et al. 1999) that is flooded during the rainy station. Dantilândia is located in southern Bahia, and the collection was made in a mountainous semideciduous forest area (SEI, 2006).

\section{Discussion}

Australopericoma dissimilis sp. nov. can be distinguished from the other species of Australopericoma by the characteristics of the hypandrium and the parameres: 1) the hypandrium shows two asymmetrical arms as well as distinct patterns of pilosity on the dorsal and ventral surfaces; and 2) the paramere p1 (Figures 13, 14, 15) has three arms while the paramere p2 has one arm (Figures 13, 14, 15).

Australopericoma dissimilis sp. nov. is the fifth species described from the Caatinga biome. The other four species are all belong to the genus Psychoda (Latreille) (Bravo et al. 2006): P. divaricata Duckhouse and $P$. zetoscota Quate from Senhor do Bonfim $\left(12^{\circ} 23^{\prime} \mathrm{S}\right.$ and $\left.40^{\circ} 12^{\prime} \mathrm{W}\right)$, P. serraorobonensis Bravo, Cordeiro \& Chagas from Rui Barbosa (12 $\left.18^{\prime} \mathrm{S} 40^{\circ} 29^{\prime} \mathrm{W}\right)$ and P. dantilandensis Bravo, Cordeiro \& Chagas from Dantilândia.

\section{Acknowledgments}

The author would like to thank the project PPBIO/MCT for financial support for the travel to Pilão Arcado. The author received financial support from CNPq (470754/2003-6) and FAPESB (PPP) and has a research grant from CNPq (307357/2003-1).

\section{References}

BARRETO, A.M.F., SUGUIO, K., OLIVEIRA, P.E. \& TATUMI, S.H. 1999. The stabilized sand dune field of the middle São Francisco river, Bahia state, Brazil. In Sítios Geológicos e Paleontológicos do Brasil (C. Schobbenhaus, D.A. Campos, E.T. Queiroz, M. Winge \& M. Berbert-Born, eds.). http://www.unb.br/ig/sigep/sitio056/sitio056.htm (last access in 18/02/2007).

BEHLING, H., ARZ, H.W., PÄTZOLD, J., WEFER, G. 2000. Late Quaternary vegetational and climate dynamics in northeastern Brazil, inferences from marine core GeoB 3104-1. Quaternary Sci. Rev. 19:981-994

BRAVO, F. 2006. The taxonomy of Neotropical Brunettiina (Diptera, Psychodidae, Psychodinae, Mormiini) with descriptions of ten new species from Brazil and comments on the generic classification of this subtribe. Zootaxa. (1134):1-28

BRAVO, F., CORDEIRO, D., CHAGAS, C. 2006. Two new species and new records of Psychoda Latreille (Diptera, Psychodidae, Psychodinae) from Brazil, with comments on supraspecific classification of the genus. Zootaxa. (1298):1-15

DUCKHOUSE, D.A. 1990. The Australasian genera of Pericomoid Psychodidae (Diptera) and the status of related Enderlein genera in the Neotropics. Invertebr. Taxon. 3:721-746.

McALPINE, J.F. 1981. Morphology and terminology: adults. In Manual of Neartic Diptera (J.F. Mcalpine, B.V. Peterson, G.E. Shewell, H.J. teskey, J.R. Vockeroth \& D.M. Wood, eds.). Research Branch, Agriculture Canada v. 1, Monograph $n^{\circ} 27$, Ottawa, p.9-63.

QUATE, L.W. 1955. A revision of the Psychodidae (Diptera) in America north of Mexico. U. Calif. Publ. Ent. 10:103-273.

QUATE, L.W. \& BROWN, B.V. 2004. Revision of neotropical Setomimini (Diptera: Psychodidae: Psychodinae). Contribution in Science: Natural History Museum of Los Angeles County. (500):1-117. 
QUEIROZ, L.P. 2006. The Brazilian Caatinga: phytogeographical patterns inferred from distribution data of the Leguminosae. In Neotropical Savannas and Dry Forests: Diversity, Biogeography, and Conservation. (R.T. Pennington, G.P. Lewis, J.A. Ratter, eds.). Taylor \& Francis, CRC Press, Boca Raton, p.113-149.
SEI. 2006. Informações geográficas: vegetação. http://www.sei.ba.gov.br (last accesses 18/02/ 2007). 